\title{
Truly low and high thromboembolic risk - impact of risk scores in real life
}

\author{
Tomasz Ciurus, Sebastian Sobczak, Małgorzata Lelonek \\ Department of Cardiology, Chair of Cardiology and Cardiac Surgery, Medical University of Lodz, Poland
}

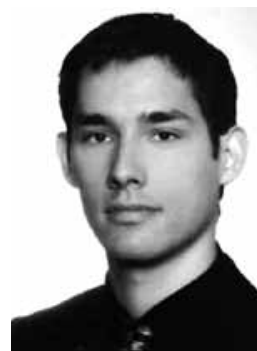

Kardiochirurgia i Torakochirurgia Polska 2014; 11 (1): 1-6

\begin{abstract}
Background: Anticoagulation therapy is followed by analysis of factors used in the CHA2DS2-VASc score and assessing the risk of bleeding (HAS-BLED).

The aim of the study was to evaluate in 'real life' risk stratification scores in nonvalvular atrial fibrillation (AF).

Material and methods: From 81 consecutive patients who had not yet received anticoagulation, 68 were finally enrolled after exclusion criteria. Patients were analyzed related to risk scores: CHADS2 $\geq 2$ (group I) vs. CHADS2 $<2$ and CHA2DS2VASc score $\geq 2$ (group II) and gender. Patients at high thromboembolic risk were treated with warfarin, after consideration of the patient's decision.

Results: At high risk of thromboembolic complications were 61 patients (90\%). In 26 subjects (43\%, 15 women - 57\%) indication for anticoagulation was established by CHA2DS2-VASc. When compared to CHADS2 $\geq 2$, these patients were younger (72 \pm 10 years vs. $63 \pm 10$ years, $p=0.0002$ ), less frequently burdened with arterial hypertension $(p=0.03)$ and had lower risk in HAS-BLED (1.23 \pm 0.65 vs. $0.81 \pm 0.49, p=0.03)$. Seven patients (10\%) did not require anticoagulation (CHA2DS2VASC $=0)$. Compared to men, women more often had ischemic stroke ( 2 vs. $18 \%, p=0.03$ ), but less coronary artery disease (58 vs. $25 \%, p=0.005$ ). During 18 months on warfarin, bleeding occurred in 9 patients (13\%, 6 women). On dual antiplatelet therapy were 11 patients (16\%). No thromboembolic complications were recorded.
\end{abstract}

Conclusions: CHA2DS2-VASC and HAS-BLED schemata easily identify real low and high thromboembolic risk patients and bleeding risk. It seems that women present higher risk of bleeding, but less frequent use of antiplatelet therapy. Key words: warfarin, CHADS2, CHA2DS2-VASc, HAS-BLED.

\section{Streszczenie}

Wstęp: Decyzja o doustnym leczeniu przeciwzakrzepowym następuje po analizie czynników demograficznych i klinicznych z użyciem skali CHA2DS2-VASc oraz oszacowaniu ryzyka wystąpienia powikłań krwotocznych (HAS-BLED).

Celem badania była ocena w codziennej praktyce stratyfikacji ryzyka zakrzepowo-zatorowego w niezastawkowym migotaniu przedsionków.

Materiał i metody: Spośród 81 kolejnych pacjentów dotychczas nieleczonych przeciwzakrzepowo, po uwzględnieniu kryteriów wykluczających, ostatecznie badaniem objęto 68. Pacjentów analizowano w zależności od ryzyka wystąpienia powikłań zatorowych: CHADS2 $\geq 2$ (grupa I) vs CHADS2 < 2 i CHA2DS2-VASc $\geq 2$ (grupa II) oraz płci. Doustne leczenie przeciwzakrzepowe prowadzono warfaryną, po uwzględnieniu preferencji pacjenta. Wyniki: Do grupy wysokiego ryzyka powikłań zatorowych zakwalifikowano 61 pacjentów (90\%). U 26 pacjentów (43\%), w tym 15 kobiet (57\%), kwalifikacja ta była możliwa jedynie przy zastosowaniu skali CHA2DS2-VASc. W porównaniu z grupą CHADS2 $\geq 2$ chorzy ci byli młodsi ( $72 \pm 10$ vs $63 \pm 10$ lat, $p=0,0002)$, rzadziej obciążeni nadciśnieniem tętniczym ( $p=0,03$ ), a ryzyko krwawień było $u$ nich niższe (HAS-BLED $1,23 \pm 0,65$ vs 0,81 $\pm 0,49, p=0,03)$. Leczenia przeciwzakrzepowego nie wymagało (CHA2DS2-VASc $=0) 7$ chorych $(10 \%)$. W porównaniu z mężczyznami u kobiet częściej w wywiadzie występował udar niedokrwienny mózgu (2 vs 18\%, $p=0,03$ ), rzadziej choroba wieńcowa (58 vs $25 \%, p=0,005$ ). W trakcie 18-miesięcznej obserwacji leczenia warfaryną incydenty krwawienia wystąpiły u 9 chorych (13\%), w tym 6 kobiet (67\%). Podwójną terapię przeciwpłytkową otrzymywało 11 chorych (16\%). Nie zarejestrowano powikłań zatorowych.

Wnioski: Zastosowanie skal CHA2DS2-VASc i HAS-BLED pozwala w łatwy i precyzyjny sposób zidentyfikować pacjentów prawdziwie niskiego i wysokiego ryzyka powikłań zatorowych oraz podwyższonego ryzyka krwawień. Wydaje się, że kobiety są obarczone wyższym ryzykiem krwawień, pomimo rzadszego stosowania leków przeciwpłytkowych.

Stowa kluczowe: warfaryna, CHADS2, CHA2DS2-VASc, HAS-BLED. 


\section{Introduction}

Anticoagulation therapy with warfarin is highly effective at reducing thromboembolic events (TE), but is associated with a higher risk of major bleeding compared to new oral anticoagulants [antithrombotic drugs - Xa (rivaroxaban, apixaban) and Ila inhibitors (dabigatran)] [1, 2]. They appear to have a favorable safety profile, particularly with the decreased risk for intracranial bleeding [3]. However, the clinical decision on antithrombotic management should be based on the balance between an individual's thromboembolic and hemorrhagic risk. The most commonly used scheme to determine this risk of TE in patients with nonvalvular atrial fibrillation (AF) was the CHADS2 score [4]. A limitation of this scale was a large part of the eligibility of patients as intermediate risk and skipping other potential risk factors for TE, such as myocardial infarction, complex aortic plaque, peripheral artery disease, female sex and age 65-74. The additional risk factors have been expressed in the CHA2DS2-VASc score [4]. Finally in current guidelines, the CHA2DS2-VASc score is crucial to decide whether or not to anticoagulate [5].

Anticoagulant therapy carries a risk of bleeding, and major bleeding such as intracranial bleeds can be catastrophic. The HAS-BLED score is a simple and user-friendly tool for the assessment of bleeding risk before starting anticoagulation [4]. A HAS-BLED score of 3 points or more indicates increased one-year bleed risk on anticoagulation sufficient to justify caution or more regular review. That risk includes intracranial bleeding, bleeding requiring hospitalization, one with a hemoglobin drop $>2 \mathrm{~g} / \mathrm{l}$ or one that needs transfusion [6].

The aim of the study was to evaluate in 'real life' risk stratification scores in patients with nonvalvular sustained AF who have not yet received anticoagulation.

\section{Material and methods}

From 81 consecutive patients with the inclusion criterion as sustained nonvalvular AF, who had not been treated with

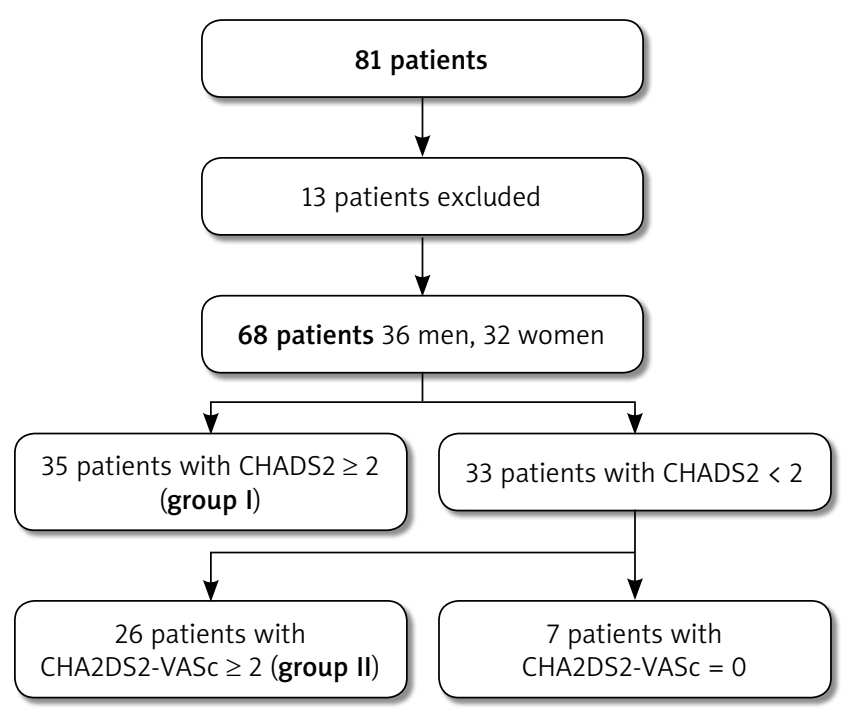

Fig. 1. Recruitment patients for the study anticoagulants, finally 68 were enrolled in the study. Patients with unstable arterial hypertension (> 160/110 mm Hg), alcohol abuse, a serious incident of bleeding requiring blood transfusion, bleeding disorder, liver disease (ALT > 3 times the upper reference level), and those who did not agree to further contact were excluded from the study $(n=13)$ (Fig. 1).

We collected the following data: demographic (age, sex), clinical (concomitant diseases, medications, a history of thromboembolic and bleeding events), and basic laboratory (morphology, electrolytes, GFR, glucose, lipids, liver enzymes, bilirubin, C-reactive protein). A follow-up was performed to ascertain outcomes: clinical events (stroke/ TIA, peripheral embolism, bleeding), change in antithrombotic therapy (discontinuation, duration on therapy); medical history update; and INR records in relation to therapeutic range. Hemorrhage included major and minor bleeding. Major bleeding was defined as an intracranial hemorrhage, a decrease in blood hemoglobin level of more than $5.0 \mathrm{~g} / \mathrm{dl}$, the need for a transfusion of two or more units of blood, the need for corrective surgery, or any combination of these events. Minor bleeding was defined as a subcutaneous ecchymosis or hematoma, gastrointestinal bleeding, urinary bleeding or bloody sputum. Hypertension, diabetes, and lipid disorders were diagnosed according to the latest recommendations, as well as the implementation of antiplatelet therapy.

For each patient CHADS2 and CHA2DS2-VASc scores were calculated. The CHADS2 score is based on a point system in which 2 points are assigned for a history of stroke or TIA and 1 point each is assigned for age $\geq 75$ years, a history of hypertension, diabetes, or recent cardiac failure [4]. The CHA2DS2-VASc scale gives two points for age of $\geq 75$ years, and in addition to factors of the CHADS2 score, one point each for age 65-74 years, vascular disease, and female sex (Table I) [4]. The bleeding risk of our patients was assessed by the HAS-BLED score [assigning one point each for the presence of hypertension, abnormal renal/ liver function, stroke, bleeding history or predisposition (e.g. bleeding diathesis, anemia), labile INR (International Normalized Ratio), elderly (> 65 years), and drugs/alcohol concomitantly] [4].

Initially, the risk of TE was calculated on the basis of the CHADS2 score. Next, in patients with CHADS2 < 2 the risk of TE was re-estimated by the CHA2DS2-VASc score. Warfarin was indicated in patients at high risk for TE (CHADS2 or CHA2DS2-VASC $\geq 2$ ), after consideration of the patient's decision.

Study groups were analyzed related to scores: CHADS2 $\geq 2$ (group I, $n=35$ ) vs. CHADS $<2$ and CHA2DS2-VASC score $\geq 2$ (group II, $n=26$ ) and gender.

The local Bioethics Committee approved the study and informed consent was obtained from all participants.

\section{Statistical analysis}

Continuous variables are presented as mean values $\pm \mathrm{SD}$ or medians with interquartile ranges (IQR) in case of 
their non-normal distribution. An independent $t$-test (when the distribution in both groups was normal) or the MannWhitney $U$ test (in the absence of normal distribution of measured variables) was used to evaluate differences in the continuous factors between the groups. $\chi^{2}$ independent test was used to investigate the relationship between scores (CHADS2, CHA2DS2-VASc) and qualitative variables. Analysis was performed with Statistica version 9.0 software. $P$ values $<0.05$ were considered to be statistically significant.

\section{Results}

The baseline characteristics of patients are summarized in Table II. The studied population consisted mainly of older patients, 21 patients (31\%) were $\geq 75$ years old and 18 (26\%) were aged $65-74$. Nineteen patients $(27 \%)$ had experienced myocardial infarction, 10 (15\%) stroke, 13 subjects (19\%) had diabetes mellitus, and 5 (7\%) peripheral artery disease. The most frequent was hypertension (73\%), followed by dyslipidemia (72\%) and coronary artery disease (42\%). Patients had preserved left ventricular systolic function (mean $53 \pm 12 \%$, median $56 \%$ ) and no symptoms of heart failure.

Almost half of patients were women (47\%). Compared to men, women had significantly more often a history of ischemic stroke ( 2 vs. $18 \%, p=0.03$ ), but less coronary heart
Tab. I. Risk factors for stroke and thrombo-embolism in non-valvular AF according to CHADS2 and CHA2DS2-VASc score [4]

\begin{tabular}{|c|c|c|}
\hline & Condition & Points \\
\hline C & $\begin{array}{l}\text { Congestive } \\
\text { heart failure }\end{array}$ & 1 \\
\hline $\mathrm{H}$ & Hypertension & 1 \\
\hline A & Age $>75$ years & 1 \\
\hline D & Diabetes & 1 \\
\hline $\mathrm{S}$ & $\begin{array}{l}\text { Prior stroke or } \\
\text { transient } \\
\text { ischaemic attack }\end{array}$ & 2 \\
\hline
\end{tabular}

\begin{tabular}{lcc} 
& Condition & Points \\
C & $\begin{array}{c}\text { Congestive } \\
\text { heart failure }\end{array}$ & 1 \\
\hline H & Hypertension & 1 \\
\hline A & Age $>75$ years & 2 \\
\hline D & Diabetes & 1 \\
\hline S & $\begin{array}{c}\text { Prior stroke or } \\
\text { transient } \\
\text { ischaemic attack }\end{array}$ & 2 \\
\hline V & Vascular disease & 1 \\
\hline A & $\begin{array}{c}\text { Aged 65-74 } \\
\text { years }\end{array}$ & 1 \\
\hline Sc & $\begin{array}{c}\text { Sex category } \\
\text { (female) }\end{array}$ & 1 \\
\hline
\end{tabular}

disease (58 vs. $25 \%, p=0.005$ ). Women had higher levels of HDL (1.47 vs. $1.21 \mathrm{mg} / \mathrm{dl}, p=0.003$ ), and lower hemoglobin (13.5 vs. $14.2 \mathrm{~g} / \mathrm{dl}, p=0.05)$ and hematocrit (40.4 vs. $43.4 \%, p=0.02$ ) than men. In analysis according to gender, the studied population did not differ in age, body mass index (BMI), daily doses of warfarin, scale HAS-BLED, high-

Tab. II. Characteristics of the studied patients

\begin{tabular}{|c|c|c|c|c|c|c|c|}
\hline Parameter & Mean & SD & Median & Minimum & Maximum & Q25 & Q75 \\
\hline Age (years)* & 65.75 & 13.2 & 67 & 21 & 90 & 60.5 & 76 \\
\hline BMI $\left(\mathrm{kg} / \mathrm{m}^{2}\right)^{\star}$ & 28.34 & 4.91 & 27.77 & 18.01 & 42.97 & 24.75 & 30.74 \\
\hline $\mathrm{CHADS2}^{*}$ & 1.76 & 1.16 & 2 & 0 & 5 & 1 & 2 \\
\hline CHA2DS2-VASc* & 3.00 & 1.58 & 3 & 0 & 8 & 2 & 4 \\
\hline HAS-BLED* & 0.99 & 0.63 & 1 & 0 & 3 & 1 & 1 \\
\hline Dose of warfarin weekly $(\mathrm{mg})^{\star}$ & 31.66 & 11.8 & 35 & 8.75 & 56 & 21 & 35 \\
\hline WBC $(1000 / \mu \mathrm{l})$ & 7.53 & 2.12 & 7.6 & 3.5 & 14.9 & 6 & 9 \\
\hline $\operatorname{RBC}(m / \mu l)^{*}$ & 4.59 & 0.54 & 4.6 & 3.64 & 6.06 & 4.12 & 4.92 \\
\hline HGB (g/dl) & 13.85 & 1.52 & 13.95 & 9.7 & 17.2 & 12.7 & 14.8 \\
\hline HCT (\%) & 42.05 & 6.61 & 42.5 & 4.4 & 54.4 & 38.5 & 45.5 \\
\hline PLT $(1000 / \mu \mathrm{l})$ & 219.45 & 91.2 & 206 & 83 & 647 & 167 & 245 \\
\hline $\mathrm{Na}^{+}(\mathrm{mg} / \mathrm{dl})$ & 138.1 & 2.47 & 138 & 133 & 145 & 137 & 140 \\
\hline $\mathrm{K}^{+}(\mathrm{mg} / \mathrm{dl})$ & 4.37 & 0.41 & 4.35 & 3.39 & 5.28 & 4.14 & 4.57 \\
\hline GFR $\left(\mathrm{ml} / \mathrm{min} / 1.72 \mathrm{~m}^{2}\right)$ & 93.46 & 33.1 & 89.52 & 39.51 & 180.27 & 65.33 & 114.05 \\
\hline Glucose (mmol/l) & 5.85 & 1.47 & 5.5 & 3.8 & 11.3 & 5 & 6.3 \\
\hline $\mathrm{TCh}(\mathrm{mmol} / \mathrm{l})$ & 4.59 & 1.25 & 4.3 & 2.4 & 8 & 3.6 & 5.35 \\
\hline $\mathrm{LDL}(\mathrm{mmol} / \mathrm{l})$ & 2.62 & 1.16 & 2.45 & 0.7 & 6 & 1.6 & 3.5 \\
\hline $\mathrm{HDL}(\mathrm{mmol} / \mathrm{l})$ & 1.33 & 0.34 & 1.30 & 0.63 & 2.23 & 1.09 & 1.56 \\
\hline TG (mmol/l) & 1.37 & 0.56 & 1.26 & 0.55 & 3.33 & 1.02 & 1.71 \\
\hline $\operatorname{ALT}(\mathrm{UI} / \mathrm{I})^{*}$ & 26.40 & 13.9 & 23 & 10 & 94 & 18 & 31 \\
\hline AST $(U I / I)^{*}$ & 24.69 & 8.31 & 23 & 11 & 62 & 19 & 28 \\
\hline Bilirubin $\mu \mathrm{mol} / /^{\star}$ & 13.10 & 7.13 & 11.15 & 0.5 & 36 & 8.35 & 16.7 \\
\hline $\operatorname{CRP}(\mathrm{mg} / \mathrm{dl})^{\star}$ & 7.46 & 10.8 & 3.1 & 0.2 & 45 & 1.2 & 6.7 \\
\hline
\end{tabular}

* non-normal distribution

$B M I$ - body mass index; WBC - white blood cells; RBC - red blood cells; HGB - hemoglobin; $\mathrm{HCT}$ - hematocrit; $P L T$ - platelets; $\mathrm{Na}^{+}$- sodium; $\mathrm{K}^{+}$- potassium; $\mathrm{Cl}^{-}$chlorine; GFR - glomerular filtration rate; TCh - total cholesterol; LDL - low density lipoproteins; HDL - high density lipoproteins; TG - triglycerides; ALT - alanine aminotransferase; AST - aspartate aminotransferase; CRP - C reactive protein; SD - standard deviation; Q25 - first quartile; Q75 - third quartile 
Tab. III. Characteristics according to gender and scales CHADS2 $\geq 2$ (group I), and CHADS2 $<2$ and CHA2DS2-VASc $\geq 2$ (group II)

\begin{tabular}{|c|c|c|c|c|c|c|}
\hline Parameter & Group I & Group II & $P$ & Men & Women & $P$ \\
\hline Age (years)* & $72.4 \pm 10.3$ & $62.9 \pm 10.3$ & 0.0002 & $67.2 \pm 14.5$ & $64.1 \pm 11.9$ & 0.223 \\
\hline $\mathrm{BMI}\left(\mathrm{kg} / \mathrm{m}^{2}\right)^{*}$ & $28.6 \pm 5.3$ & $28.3 \pm 4.9$ & 0.902 & $28 \pm 4.8$ & $28.8 \pm 5.0$ & 0.459 \\
\hline HAS-BLED* & $1.2 \pm 0.7$ & $0.8 \pm 0.5$ & 0.027 & $1.0 \pm 0.51$ & $0.9 \pm 0.76$ & 0.490 \\
\hline Dose of warfarin daily $(\mathrm{mg})^{*}$ & $4.5 \pm 1.8$ & $4.4 \pm 1.6$ & 0.777 & $4.6 \pm 1.7$ & $4.5 \pm 1.8$ & 0.888 \\
\hline Dose of warfarin weekly $(\mathrm{mg})^{*}$ & $31.8 \pm 12.3$ & $30.8 \pm 11.3$ & 0.800 & $32.1 \pm 11.5$ & $31.1 \pm 12.4$ & 0.898 \\
\hline GFR $\left(\mathrm{ml} / \mathrm{min} / 1.72 \mathrm{~m}^{2}\right)^{\star}$ & $79.8 \pm 25.6$ & $99.7 \pm 30.7$ & 0.008 & $92.9 \pm 2.4$ & $94.2 \pm 34.6$ & 0.875 \\
\hline Glucose $(\mathrm{mmol} / \mathrm{l})^{*}$ & $6.1 \pm 1.6$ & $5.6 \pm 1.5$ & 0.274 & $5.7 \pm 1.3$ & $6.1 \pm 1.7$ & 0.225 \\
\hline $\mathrm{TCh}(\mathrm{mmol} / \mathrm{l})$ & $4.2 \pm 0.9$ & $5.0 \pm 1.4$ & 0.011 & $4.3 \pm 1.2$ & $4.9 \pm 1.3$ & 0.096 \\
\hline LDL (mmol/l) & $2.3 \pm 0.9$ & $2.9 \pm 1.3$ & 0.022 & $2.5 \pm 1.1$ & $2.8 \pm 1.2$ & 0.254 \\
\hline $\mathrm{HDL}(\mathrm{mmol} / \mathrm{l})$ & $1.4 \pm 0.31$ & $1.4 \pm 0.4$ & 0.551 & $1.2 \pm 0.2$ & $1.5 \pm 0.4$ & 0.003 \\
\hline TG $(\mathrm{mmol} / \mathrm{l})$ & $1.3 \pm 0.51$ & $1.4 \pm 0.6$ & 0.221 & $1.4 \pm 0.7$ & $1.3 \pm 0.4$ & 0.751 \\
\hline $\operatorname{ALT}(I U / I)^{*}$ & $24.5 \pm 15.6$ & $26.2 \pm 10.1$ & 0.069 & $25.2 \pm 11.8$ & $27.8 \pm 16.1$ & 0.536 \\
\hline AST $(I U / I)^{*}$ & $24.1 \pm 9.0$ & $24.4 \pm 6.6$ & 0.421 & $24.6 \pm 6.6$ & $24.7 \pm 10.0$ & 0.511 \\
\hline Bilirubin $(\mu \mathrm{mol} / \mathrm{l})^{*}$ & $11.6 \pm 5.5$ & $14.4 \pm 8.0$ & 0.391 & $13.5 \pm 7.1$ & $12.7 \pm 7.3$ & 0.491 \\
\hline $\operatorname{CRP}(\mathrm{mg} / \mathrm{dl})^{*}$ & $6.1 \pm 9.4$ & $6.7 \pm 9.7$ & 0.614 & $9.2 \pm 13.7$ & $5.2 \pm 4.4$ & 0.522 \\
\hline Stroke & 17.14 & 3.85 & 0.228 & 2.78 & 18.6 & 0.030 \\
\hline CAD & 54.29 & 34.62 & 0.127 & 58.33 & 25.00 & 0.005 \\
\hline Myocardial infarction & 37.14 & 19.23 & 0.129 & 30.56 & 25.00 & 0.610 \\
\hline Diabetes & 28.57 & 11.54 & 0.108 & 13.89 & 25.00 & 0.244 \\
\hline Dyslipidemia & 77.14 & 69.23 & 0.487 & 77.78 & 65.63 & 0.264 \\
\hline Hypertension & 88.57 & 65.38 & 0.028 & 75.00 & 71.88 & 0.770 \\
\hline Bleeding & 17.14 & 11.54 & 0.541 & 8.33 & 18.75 & 0.364 \\
\hline
\end{tabular}

The results are presented as $\%$ and mean value $\pm S D$

* Non-normal distribution

$B M I$ - body mass index; GFR - glomerular filtration rate; TCH - total cholesterol; LDL - low density lipoproteins; HDL - high density lipoproteins; TG - triglycerides; $A L T$ - alanine aminotransferase; $A S T$ - aspartate aminotransferase; $C R P-C$ reactive protein; $C A D$ - coronary artery disease; $S D$ - standard deviation

sensitive C-reactive protein (hsCRP), and kidney and liver function (Table III).

Distribution of CHADS2 and CHA2DS2-VASc scores is shown in Fig. 2. For the total population the median CHADS2 score was 2 points and CHA2DS2-VASc 3. Taking

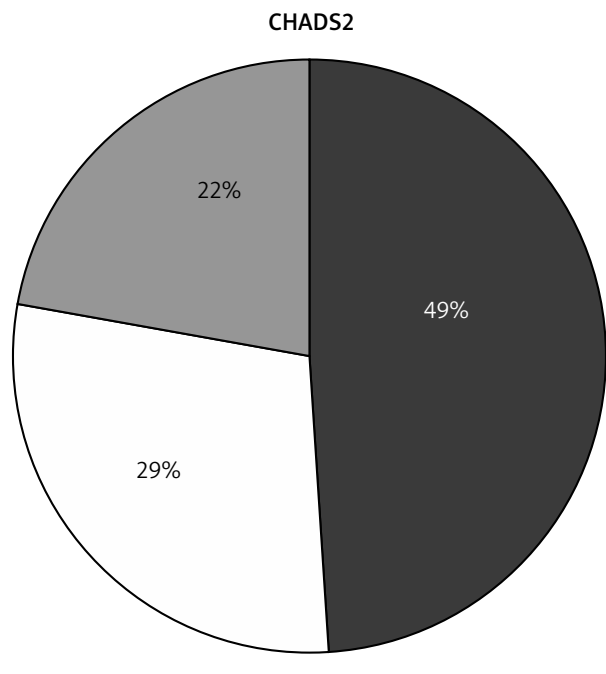

$\square$ 0-1 (33 pts.) $\square 2$ (20 pts.) $\square>3$ (15 pts.) into account the mentioned two scales 61 patients (90\%) were at high risk for thromboembolic complications. In 26 patients (43\%) with one point on CHADS2, qualifications for vitamin $\mathrm{K}$ antagonist (VKA) therapy was only possible by using CHA2DS2-VASc. In this group were 15 women (57\%).

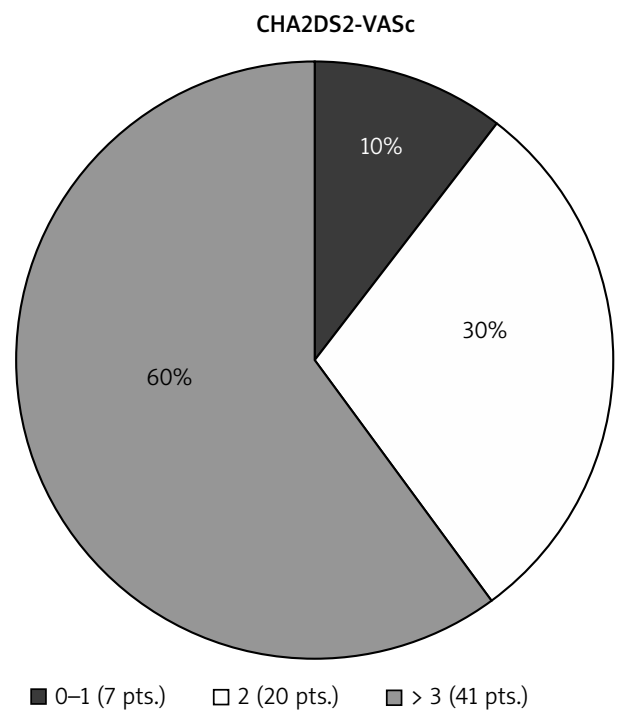

Fig. 2. Distribution of patients according to CHADS2 and CHA2DS2-VASc risk stratification 
Seven patients (10\%), all men, did not require anticoagulation (CHA2DS2-VASC $=0)$. In the studied population there were no patients with $\mathrm{CHA} 2 \mathrm{DS} 2-\mathrm{VASC}=1$.

Concomitant aspirin and VKA was used by $42 \%$ and dual antiplatelet therapy by $16 \%$ of patients.

During the $18 \pm 2.35$ months of follow-up the median daily dose of warfarin was $5 \mathrm{mg}$ (range 1.25-8 mg) with therapeutically optimal INR.

The total study group was at low risk of bleeding, with a median HAS-BLED score of 1 (98\% with HAS-BLED $\leq 2$ [low risk]). Among hemorrhage events, there was no major bleeding. Minor bleeding was observed in 9 (13\%) patients, including 6 women (67\%): nose (5 cases), the urinary tract (3) and gastrointestinal tract (1). Three men with bleeding received one of the antiplatelet drugs.

During the 18 months of follow-up no incident of thromboembolic complication was recorded.

Patients of group II compared to group I were younger $(p=0.0002)$, with prevalence of women (58 vs. $43 \%$, $p=0.25$ ), and less frequently burdened with arterial hypertension $(p=0.03)$. In this group there were higher glomerular filtration rate $(p=0.008)$, total cholesterol level $(p=0.01)$ and LDL values $(p=0.02)$. Moreover, group II patients had a lower value of HAS-BLED $(p=0.03)$. The characteristics of the studied groups are presented in Table III.

\section{Discussion}

The main finding of our study is that the CHA2DS2VASc score identified 26 subjects more at high risk of thromboembolic complications in comparison to CHADS2, which was a large part of all requiring VKA (43\%). According to CHADS2, these patients were qualified to moderate risk level with $\mathrm{CHADS} 2=1$. The crucial factors of high risk of TE in group II were age, female gender and vascular disease, particularly myocardial infarction.

Similar results were observed in a Danish national registry of 73,538 non-anticoagulated patients with nonvalvular AF [7]. As in our study, a large percentage (46\%) of respondents were women. They proved that CHA2DS2-VASC performed better than CHADS2 for categorization into risk groups for stroke and for identification of patients at truly low risk and that not all risk factors were associated with an equal risk of TE. A particularly high risk was associated with age $\geq 65$, gender and diabetes mellitus [8]. Opposite to our patients, the Danish population was older (31 vs. 54\% $\geq 75$ years), less frequently burdened with arterial hypertension (73 vs. $40 \%$ ) and vascular disease (42 vs. 17\%) [7].

Similar to our results, Friberg et al. found that women with AF are at higher risk for ischemic stroke than men [9]. However, in a recently published study Mikkelsen et al. revealed that female gender is associated with an increased risk of stroke for AF only in patients aged $>75$ years (HR 1.2, 95\% Cl: 1.12-1.28) [10].

Antithrombotic therapy to prevent thromboembolism is recommended for all patients with $A F$, except those who are at low risk or with contraindications [5]. Atrial fibrillation patients classified as 'low-risk' using CHADS2 score $=0$ have stroke rates of $1.5 \%$ per year, so they are not 'truly low-risk'. The evidence shows that CHA2DS2-VASc score reclassifies $26 \%$ of patients with a CHADS2 score of 1 to a low risk of stroke [11]. Therefore, CHA2DS2-VASc is better at identifying 'truly low-risk' patients with AF, who do not need any antithrombotic therapy $[5,12]$. In our study $10 \%$ of patients had $\mathrm{CHA} 2 \mathrm{DS} 2-\mathrm{VASC}=0$.

Those with a CHA2DS2-VASc score of $\geq 2$ (the age-adjusted rate of stroke per year 2.2\%) are at high risk of TE and should be managed with oral anticoagulation, whether with warfarin or novel oral anticoagulants that overcome the limitations or disadvantages [5]. For those with a CHA2DS2-VASc score of 1 (the age-adjusted rate of stroke per year $1.3 \%$ ), oral anticoagulation therapy with VKA or direct thrombin inhibitor, or oral factor $\mathrm{Xa}$ inhibitor is considered, based upon an assessment of the risk of bleeding complications and patient preferences [5].

The decision to anticoagulate is based not only on thromboembolic risk but also on the risk of bleeding, and the European guidelines on atrial fibrillation incorporate a bleeding prediction scheme HAS-BLED to help with this decision making $[4,5]$. It is recognized that several risk factors predisposing to bleeding are also risk factors for stroke, and although some schemas (e.g. CHADS2) have modest value for predicting stroke, they are very good at predicting a patient's risk of bleeding [13].

The type and severity of comorbid disorders are the most important risk factors for anticoagulant-related bleeding. Cardiovascular disease, liver dysfunction, and severe renal impairment are associated with increased risk of bleeding $[14,15]$. We observed only minor bleeding events, mostly from the upper respiratory (44\%) and urinary tract (33\%). Absence of major bleeding in our study may result from preserved renal function, especially in our younger patients (group II). In a Dutch center the most prevalent bleeding events were from the gastrointestinal tract, even $40 \%$ of all events, as major bleeding requiring a blood transfusion [16]. Opposite to our patients, this population was older (mean age 66 vs. 73 years), less burdened with arterial hypertension (73 vs. $47 \%$ ) and vascular diseases (42 vs. $11 \%)$. Similar to our study, patients received aspirin with VKA (42 vs. 39\%), but less dual antiplatelet therapy (16 vs. $3.5 \%$ ) [16]. Despite the low risk of bleeding (median HASBLED $=1$ ) in our population, there were several incidents of minor bleeding (13\% compared to $9 \%$ in the other studies) $[17,18]$. Possibly that can be explained by concomitant use of aspirin and antiplatelet drugs. However, in such cases in the literature there was observed more frequently major bleeding [16].

Based on our results, it seems that some caution and regular review of the patient is needed following the initiation of antithrombotic therapy not only in the high-risk bleeding group (HAS-BLED > 3) but also in patients with low or intermediate risk (HAS-BLED $\leq 2$ ), particularly with concomitant use of antiplatelet drugs. Close control of INR in the therapeutic range can reduce the number of bleeding complications, as confirmed in other studies [17]. 
Current practice guidelines for stroke prophylaxis recommend warfarin for patients at high risk for stroke including those over 75 years of age or younger patients with additional risk factors [19]. Although these recommendations are strongly supported by the clinical trial evidence, studies show that many patients are not receiving appropriate VKA therapy. The approach may be changed with a new generation of anticoagulant drugs, such as dabigatran and rivaroxaban. They offer an interesting alternative to warfarin, because blood tests for monitoring INR are not required and there is lower bleeding risk while offering similar results in terms of efficacy. Their main disadvantage is the low experience of their use and no specific antidote for an overdose [20].

The challenge is defining patients who would best benefit from thromboprophylaxis, and showing how to deliver it in the most effective and safe way. Due to the risk of bleeding complications, there is often suboptimal implementation of prevention among patients with the risk of TE. An individual approach to each patient, including risk stratification with the available scores, helps reduce the number of complications in anticoagulation.

\section{Limitations}

The main limitation of the study is the small study group and therefore a multivariate analysis was not performed. Moreover, we analyzed data from a single academic center, and thus the strength of the evidence cannot be compared to that obtained in randomized studies. Despite these constraints, the results are consistent with other studies.

\section{Conclusions}

The reclassifying approach with the implications of CHA2DS2-VASC and HAS-BLED schemata provides some improvement over the CHADS2 score, with the identification of real low and high risk patients. In the era of antiplatelet therapy the bleeding risk should be carefully evaluated. It seems that women present higher risk of bleeding, although less frequent use of antiplatelet therapy.

The authors declare no conflicts of interest.

\section{References}

1. Lip GY, Edwards SJ. Stroke prevention with aspirin, warfarin and ximelagatran in patients with non-valvular atrial fibrillation: a systematic review and meta-analysis. Thrombosis Res 2006; 118: 321-323.

2. O'Dell KM, Igawa D, Hsin J. New oral anticoagulants for atrial fibrillation: a review of clinical trials. Clin Ther 2012; 34: 894-901.

3. Miller CS, Grandi SM, Shimony A, Filion KB, Eisenberg MJ. Meta-analysis of efficacy and safety of new oral anticoagulants (dabigatran, rivaroxaban, apixaban) versus warfarin in patients with atrial fibrillation. Am J Cardiol 2012; 110: 453-460.

4. European Heart Rhythm Association; European Association for Cardio-Thoracic Surgery, Camm AJ, Kirchhof P, Lip GY, Schotten U, Savelieva I, Ernst S, Van Gelder IC, Al-Attar N, Hindricks G, Prendergast B, Heidbuchel H, Alfieri O, Angelini A, Atar D, Colonna P, De Caterina R, De Sutter J, Goette A, Gorenek B,
Heldal M, Hohloser SH, Kolh P, Le Heuzey JY, Ponikowski P, Rutten FH. Guidelines for the management of atrial fibrillation: the Task Force for the Management of Atrial Fibrillation of the European Society of Cardiology (ESC). Eur Heart J 2010; 31: 2369-2429.

5. Camm AJ, Lip GY, De Caterina R, Savelieva I, Atar D, Hohnloser SH, Hindricks G, Kirchhof P; ESC Committee for Practice Guidelines-CPG; Document Reviewers 2012 focused update of the ESC Guidelines for the management of atrial fibrillation: an update of the 2010 ESC Guidelines for the management of atrial fibrillation - developed with the special contribution of the European Heart Rhythm Association. Europace 2012; 14: 1385-1413.

6. Pisters R, Lane DA, Nieuwlaat R, de Vos CB, Crijns HJ, Lip GY. A novel user friendly score (HAS-BLED) to assess one-year risk of major bleeding in atrial fibrillation patients: The Euro Heart Survey. Chest 2010; 138: 1093-1100.

7. Olesen JB, Lip GY, Hansen ML, Hansen PR, Tolstrup JS, Lindhardsen J, Selmer C, Ahlehoff O, Olsen AM, Gislason GH, Torp-Pedersen C. Validation of risk stratification schemes for predicting stroke and thromboembolism in patients with atrial fibrillation: nationwide cohort study. Br Med J 2011; 342: d124.

8. Lip GY, Nieuwlaat R, Pisters R, Lane DA, Crijns HJ. Refining clinical risk stratification for predicting stroke and thromboembolism in atrial fibrillation using a novel risk factor-based approach: the Euro Heart Survey on atrial fibrillation. Chest 2010; 137: 263-272.

9. Friberg L, Benson L, Rosenqvist M, Lip GY. Assessment of female sex as a risk factor in atrial fibrillation in Sweden: nationwide retrospective cohort study. BMJ 2012; 344: e3522-e3531.

10. Mikkelsen AP, Lindhardsen J, Lip GY, Gislason GH, Torp-Pedersen C, Olesen JB. Female sex as a risk factor for stroke in atrial fibrillation: A nationwide cohort study. J Thromb Haemost 2012; 10: 1745-1751.

11. Coppens M, Eikelboom JW, Hart RG, Yusuf S, Lip GY, Dorian P, Shestakovska O, Connolly SJ. The CHA2DS2-VASc score identifies those patients with atrial fibrillation and a CHADS2 score of 1 who are unlikely to benefit from oral anticoagulant therapy. Eur Heart J 2013; 34: 170-176.

12. Taillandier S, Olesen JB, Clémenty N, Lagrenade I, Babuty D, Lip GY, Fauchier L. Prognosis in patients with atrial fibrillation and CHA(2) DS(2) -VASC Score $=0$ in a community-based cohort study. J Cardiovasc Electrophysiol 2012; 23: 708-713.

13. Hylek EM, Evans-Molina C, Shea C, Henault LE, Regan S. Major hemorrhage and tolerability of warfarin in the first year of therapy among elderly patients with atrial fibrillation. Circulation 2007; 115: 2689-2696.

14. Elliott MJ, Zimmerman D, Holden RM. Warfarin anticoagulation in hemodialysis patients: a systematic review of bleeding rates. Am J Kidney Dis 2007; 50: 433-440.

15. Marinigh R, Lane DA, Lip GY. Severe renal impairment and stroke prevention in atrial fibrillation: implications for thromboprophylaxis and bleeding risk. J Am Coll Cardiol 2011; 57: 1339-1348.

16. Guerrouij M, Uppal CS, Alklabi A, Douketis JD. The clinical impact of bleeding during oral anticoagulant therapy: assessment of morbidity, mortality and post-bleed anticoagulant management. J Thromb Thrombolysis 2011; 31: 419-423.

17. Olesen JB, Lip GY, Lindhardsen J, Lane DA, Ahlehoff O, Hansen ML, Rauns $\varnothing$ J, Tolstrup JS, Hansen PR, Gislason GH, Torp-Pedersen C. Risks of thromboembolism and bleeding with thromboprophylaxis in patients with atrial fibrillation: A net clinical benefit analysis using a «real world nationwide cohort study. Thromb Haemost 2011; 106: 739-749.

18. Wieloch M, Själander A, Frykman V, Rosenqvist M, Eriksson N, Svensson PJ. Anticoagulation control in Sweden: reports of time in therapeutic range, major bleeding, and thrombo-embolic complications from the national quality registry AuriculA. Eur Heart J 2011; 32: 2282-2289.

19. Goldstein LB, Bushnell CD, Adams RJ, Appel LJ, Braun LT, Chaturvedi S, Creager MA, Culebras A, Eckel RH, Hart RG, Hinchey JA, Howard VJ, Jauch EC, Levine SR, Meschia JF, Moore WS, Nixon JV, Pearson TA. Guidelines for the primary prevention of stroke: A guideline for healthcare professionals from the American Heart Association/American Stroke Association. Stroke 2011; 42: 517-584.

20. Flaker G, Ezekowitz M, Yusuf S, Wallentin L, Noack H, Brueckmann M, Reilly P, Hohnloser SH, Connolly S. Efficacy and safety of dabigatran compared to warfarin in patients with paroxysmal, persistent, and permanent atrial fibrillation: results from the RE-LY (Randomized Evaluation of Long-Term Anticoagulation Therapy) study. J Am Coll Cardiol 2012; 59: 854-855. 